\title{
EX ANTE AUDIT SEBAGAI UPAYA PENCEGAHAN FRAUD
}

\author{
Helti Nur Aisyiah \\ Institut Agama Islam Negeri Surakarta \\ aisyah76@gmail.com \\ Fahri Ali Ahzar \\ Institut Agama Islam Negeri Surakarta \\ paqriea@gmail.com
}

Received: 28-09-2017

Revised: 22-10-2017

Accepted: $30-10-2017$

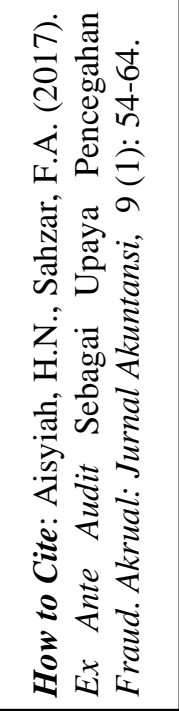

ABSTRACT

This study aims to find out how the efforts of PTKIN $X$ in an effort to overcome fraud (fraud). Researchers conduct research with a qualitative approach to the subject of research Internal Supervisory Unit (SPI) as an institution that has authority in checking budget management. The results showed that PTKIN X started doing ex ante audit by checking the Terms of Reference (KAK), proposal, or Term of Referendum (TOR) of each activity. Ex ante audit is done by looking at the completeness of the documents, price fairness, and relevance between the budget and activities written on the TOR. Ex ante audit is done to minimize the findings.

Keywords: audit, budge, ex ante, fraud, internal control

\section{ABSTRAK}

Penelitian ini bertujuan untuk mengetahui bagaimana upaya PTKIN X dalam upaya mengatasi kecurangan (fraud). Peneliti melakukan penelitian dengan pendekatan kualitatif dengan subjek penelitian Satuan Pengawas Internal (SPI) sebagai lembaga yang mempunyai wewenang dalam memeriksa pengelolaan anggaran. Hasil penelitian menunjukkan bahwa PTKIN X mulai melakukan ex ante audit dengan memeriksa Kerangka Acuan Kerja (KAK), proposal, atau Term of Referendum (TOR) tiap kegiatan. Ex ante audit dilakukan dengan melihat kelengkapan dokumen, kewajaran harga, dan relevansi antara anggaran dan kegiatan yang tertulis pada KAK. Ex ante audit dilakukan untuk meminimalisasi temuan.

Kata Kunci: anggaran, audit, ex ante, fraud, satuan pengawas internal

\section{PENDAHULUAN}

Pengelolaan keuangan di instansi sektor publik merupakan hal yang rentan korupsi. Kondisi ini sesuai dengan data dari Indonesia Corruption Watch (ICW) tentang korupsi di perguruan tinggi dalam rentang waktu 10 tahun terakhir. ${ }^{1}$ Data tersebut menunjukkan sedikitnya 37 kasus dari tahun 2006 hingga Agustus 2016. Dari keseluruhan kasus korupsi tersebut, ICW mencatat terdapat sedikitnya 65 pelaku berasal dari lingkungan civitas akademika, pegawai pemerintah daerah, dan pihak swasta.

ICW juga menemukan 12 pola korupsi di perguruan tinggi. Dari 12 pola yang ditemukan, korupsi dalam pengadaan barang dan jasa menjadi modus yang paling banyak digunakan. Tercatat 14 dari 37 kasus yang ditemukan menggunakan modus pengadaan barang dan 
jasa. Selain dalam pengadaan barang dan jasa, dana penelitian, dan beasiswa mahasiswa juga menjadi objek korupsi.

Pada korupsi dana penelitian, umumnya diselewengkan untuk kegiatan yang sama sekali tidak terkait dengan dana penelitian, seperti kepentingan pribadi dan perjalanan dinas, sedangkan korupsi dana beasiswa umumnya berupa pemotongan besaran beasiswa atau pengambilalihan seluruh atau sebagian dana beasiswa, membuat dana yang tersedia tidak tersalurkan kepada mahasiswa. Pola-pola lain yang ditemukan ICW adalah Korupsi dana hibah atau CSR, korupsi anggaran internal perguruan tinggi, korupsi penjualan aset milik perguruan tinggi, dan korupsi dana Sumbangan Pembinaan Pendidikan (SPP) mahasiswa.

Korupsi dalam perguruan terjadi karena kecurangan (fraud) yang rutin dilakukan, bahkan bisa menjadi kebiasaan. Banyaknya sumber anggaran pada instansi sektor publik, khususnya perguruan tinggi, juga mendorong oknumoknum pengguna anggaran untuk melakukan tindakan kecurangan. Berdasarkan data ICW dalam 10 tahun terakhir, oknum-oknum tersebut adalah 32 pegawai dan pejabat struktural di tingkatan fakultas atau universitas, 13 rektor atau wakil rektor, 5 orang dosen, 2 pejabat pemerintah daerah, dan 10 pihak swasta.

Sholihah, dkk (2016) menemukan pola fraud yang menjadi temuan BPK, yaitu: perawatan kendaraan bermotor; cetak dan penggandaan; pemeliharaan alat kantor dan rumah tangga; makanan dan minuman pegawai; mamin tamu; mamin rapat; Alat Tulis Kantor
(ATK); Bahan Bakar Minyak (BBM); alat listrik; bahan/ material; dekorasi; dokumentasi; materai; pemeliharaan; pakaian; peralatan/ bahan kebersihan; sewa, barang/jasa badan layanan umum daerah; pigura; tropy; dan makan minum kepala dan wakil kepala daerah. Sholihah, dkk (2016) nampaknya menjawab penelitian Johnson Et al. (2013) yang mengatakan bahwa auditor kesulitan mengidentifikasi perilaku tidak etis atau curang.

Sebelumnya, telah ada penelitian yang menyebutkan adanya fraud dalam bentuk pelaporan palsu, pencurian data, korupsi, pencucian uang dan pencurian uang tunai (Maria Kambria Kapardis dan Konstantinos Papastergiou, 2016). Fraud bisa dilakukan pada perencanaan hingga pelaporan. Fraud pada tahap perencanaan cenderung "bermain angka". Pola yang dilakukan adalah dengan "mengkondisikan" rincian objek belanja yang mudah SPJ-nya, menganggarkan rincian objek belanja yang tidak perlu, memark up harga dan meningkatkan kualitas dan kuantitas rincian objek belanja. Sedangkan fraud pada tahap pelaksanaan dan penatausahaan adalah dengan "memaksakan" penyerapan 100\% (Sholihah, dkk, 2016).

Fraud perlu perhatian khusus mengingat fraud yang juga merupakan kejahatan finansial dan korupsi di suatu negara memiliki dampak negative pada ekonomi dan dapat menempatkannya dalam penurunan ekonomi yang lebih dalam (Kapardis, Maria Kambria dan Konstantinos Papastergiou, 2016). 
AKRUAL: Jurnal Akuntansi, volume 9, nomor 1, Oktober 2017, (54-64)

Proses kinerja SPI akan selalu menemui potensi kecurangan yang dilakukan oleh pengguna anggaran. Albrecht, et al. (2009) mendefinisikan fraud sebagai istilah umum yang mencakup semua upaya manusia yang dirancang untuk mendapatkan keuntungan dengan memberikan keterangan palsu. Kecurangan (fraud) merupakan setiap tindakan illegal yang ditandai dengan tipu daya, penyembunyian, atau pelanggaran kepercayaan. Tindakan ini tidak tergantung pada penerapan ancaman kekerasan atau kekuatan fisik. Penipuan yang dilakukan oleh individu dan organisasi untuk: (1) memperoleh uang, kekayaan, atau jasa; (2) menghindari pembayaran atau kerugian jasa; (3) mengamankan keuntungan bisnis pribadi (Tuanakotta: 2013, 28).

Penelitian ini penting dilaksanakan mengingat bahwa pengendalian internal secara managerial, belum menyentuh pada penggunaan secara nominal dan masih terbatas pengendalian aliran kas. Asy'ari, Prasetyono, dan Haryadi (2013) mengatakan bahwa pengendalian internal masih terbatas pada audit ketaatan (compliance test), belum sampai tataran pencegahan fraud. Mark Schelker dan Reiner Eichenberger (2008) mengatakan bahwa fraud bisa diminimalisasi dengan teori tentang ex ante audit. Ex ante audit merupakan kebalikan dari ex post audit. Ex ante audit dilakukan mengingat kelemahan besar post audit yang tidak dapat mengevaluasi alokasi dana publik karena audit dilakukan setelah proses tahun anggaran selesai dan sumber daya telah dihabiskan. Jika audit hanya dilakukan di akhir pada dokumen-dokumen realisasi, fraud tidak bisa dihindari karena sudah terjadi, auditor hanya sekedar menandai temuan-temuan. Dengan demikian, ex ante audit berfungsi untuk mencari potensi temuan, sedangkan post audit untuk mencari temuan.

Selama ini, audit setelah pelaporan anggaran hanya sebatas mengetahui kecurangankecurangan. Keadaan ini akan merugikan negara dalam hal penggunaan anggaran. Permasalahan ini sebenarnya bisa diatasi dengan adanya audit sebelum penggunaan anggaran. Auditor dapat melakukan audit awal (ex ante audit) pada draft anggaran dan usulan kebijakan untuk meningkatkan transparansi dan mengurangi penggunaan dana yang berlebih dan pajak. Selain itu, dampak fiskal dari kebijakan yang diusulkan akan dapat terdeteksi lebih ini, sehingga mampu menghasilkan penggunaan dana yang berkualitas dan mengurangi asimetri informasi (Mark Schelker dan Reiner Eichenberger, 2008: 3-7). Sebenarnya, auditor mempunyai wewenang bisa melakukan deteksi dan pencegahan fraud berupa pencurian uang dan aset (Maria Krambia Kapardis dan Konstantinos Papastergiou, 2016). Berdasarkan latar belakang tersebut, peneliti ingin mengetahui bagaimana teknis ex ante audit yang dilakukan oleh PTKIN X dalam upaya meminimalisasi temuan fraud pada pengelolaan anggaran di PTKIN X tersebut.

\section{METODE}

Mendukung dan melengkapi penelitian sebelumnya, penelitian ini menggunakan metode kualitatif untuk mendapatkan data yang 
mendalam tentang teknis bagaimana ex ante audit dilakukan. Penelitian ini dilakukan dengan tiga metode pengumpulan data, yaitu wawancara, observasi partisipasi, dan pustaka. Penelitian ini berlangsung selama enam bulan terhitung per 1 Januari 2017 sesuai dengan mulai diberlakukannya ex ante audit pada PTKIN X.

Wawancara dilakukan secara mendalam terhadap para informan yang mengetahui pengelolaan keuangan di PTKIN X. Adapun para informan tersebut adalah ketua SPI, sekretaris SPI, staff SPI, auditor internal, kepala bagian perencanaan dan keuangan, kepala sub bagian perencanaan, kepala sub bagian keuangan, dan staff penyusun SPJ tiap unit, fakultas, atau lembaga. Pada teknis observasi, peneliti ikut serta dalam kegiatan-kegiatan bernuansa diskusi antara bagian keuangan dan SPI. Peneliti juga melakukan studi pustaka guna memperkuat data primer.

Menurut Bungin (2011) dua hal yang ingin dicapai dalam analisis data kualitatif, yaitu menganalisis proses berlangsungnya fenomena sosial dan memperoleh suatu gambaran yang tuntas terhadap proses tersebut dan menganalisis makna yang ada dibalik informasi, data dan proses suatu fenomena sosial itu.

Langkah-langkah analisis data dalam penelitian ini mengacu pada teknik yang dijabarkan oleh Creswell (2012), yaitu: (1) Mengolah dan mempersiapkan data untuk dianalisis; (2) Membaca keseluruhan data; (3) Menganalisis lebih detail dengan mengkoding data, mengolah materi atau informasi menjadi segmen-segmen tulisan; (4) Menerapkan proses coding untuk mendeskripsikan seting, lokasi, orang-orang, kategori-kategori dan tema-tema yg akan dianalisis; (5) Menyajikan kembali deskripsi dan tema-tema yang diperoleh dalam bentuk narasi atau laporan kualitatif; (6) Menginterpretasi atau memaknai data yang berasal dari perbandingan antara hasil penelitian dengan informasi yang berasal dari literatur atau teori.

\section{HASIL DAN PEMBAHASAN}

Pada PTKIN X, audit dilakukan oleh pihak internal dan eksternal. Audit internal dilakukan oleh Satuan Pengawas Internal (SPI) dan audit eksternal dilakukan oleh inspektorat jenderal. Ex ante audit hanya dilakukan pihak internal kampus dalam hal ini adalah Satuan Pengawas Internal (SPI) mengingat lebih banyak interaksi dengan internal. SPI disini mengawasi seluruh kegiatan dan fungsi organisasi yang bertujuan untuk mengendalikan kegiatan, meningkatkan efektivitas dan efisiensi, serta mendeteksi secara dini terjadinya penyimpangan dan ketidakpatuhan terhadap ketentuan peraturan perundang-undangan yang telah ditetapkan.

Menurut Moh Wahyudin Zarkasyi (2008), Satuan Pengawasan Internal (SPI) bertanggung jawab kepada Rektor dan seluruh unit kerja yang membawahi tugas pengawasan internal. Satuan Pengawasan Internal berfungsi dan bertugas membantu Rektor dalam memastikan pencapaian tujuan dan misi universitas dengan: (1) Melakukan evaluasi terhadap pelaksanaan program universitas; (2) Memperbaiki efektifitas proses pengendalian 
AKRUAL: Jurnal Akuntansi, volume 9, nomor 1, Oktober 2017, (54-64)

risiko; (3) Melakukan evaluasi kepatuhan universitas terhadap peraturan universitas dan perundang-undangan; (4) Memfasilitasi kelancaran pelaksanaan audit oleh auditor eksternal.

Satuan Pengawas Internal (SPI) di PTKIN X sudah terbentuk sejak November 2015 berdasarkan Keputusan Rektor PTKIN X Nomor 396 Tahun 2015. Namun, operasional SPI baru berjalan efektif per Januari 2017. Terbentuknya SPI secara operasional, yaitu meningkatnya temuan pada pengelolaan keuangan oleh auditor eksternal.

Selain kondisi internal kampus, juga didukung oleh menurunnya status laporan keuangan Kemenag dari WTP menjadi WDP. Adapun kronologi predikat laporan keuangan tiga tahun terakhir adalah, sebagai berikut.

\begin{tabular}{ll}
\hline Tahun & Predikat \\
\hline 2014 & Wajar tanpa pengecualian \\
2015 & Wajar tanpa pengecualian \\
2016 & Wajar dengan pengecualian \\
\hline sumber: data primer yang diolah, 2017.
\end{tabular}

Menurunnya predikat tersebut dikarenakan adanya fraud atas anggaran dari beberapa sumber dana, yaitu Peneriman Negara Bukan Pajak (PNBP), Bantuan Operasional Perguruan Tinggi Negeri (BOPTN), dan Rupiah Murni (RM). Berdasarkan hasil pemeriksaan BPK terhadap pengelolaan keuangan di lingkungan PTKIN, pengelolaan PNBP yang belum tertib adalah: (1) Pengelolaan Persediaan dan Aset Tetap; (2) Pendapatan BLU terlambat disetor; (3) Pemanfaatan aset oleh pihak ketiga belum didukung dengan surat perjanjian/sewa.
Kesempatan fraud terjadi karena control yang lemah (Krambia-Kapardis dan Zopiatis, 2010). Dengan demikian, perlu adanya usaha nyata untuk meningkatkan kualitas pelaporan keuangan Kemenag dari lini terbawah, termasuk PTKIN X. Pihak Kemenag pusat sudah menyusun tahapan program dalam rangka mengusahakan kembali predikat WTP, yaitu dari sisi perencanaan, penganggaran, pelaksanaan, pelaporan, monitoring, dan evaluasi.

Pada tahun 2016, PTKIN X menempati rangking 65 dari 125 satuan kerja dalam hal kualitas pelaporan keuangan. ${ }^{5}$ Sedangkan dalam hal temuan pada laporan keuangan, kebanyakan temuan terletak pada harga satuan item belanja yang melebihi standar biaya masukan. Misalnya, pada standar biaya masukan hanya memperbolehkan membelanjakan makan siang maksimal Rp 30.000, unit menggunakan jasa catering melebihi standar biaya itu

Harga satuan hingga biaya total yang digunakan bisa dilihat pada Rincian Anggaran Belanja (RAB). Pada tahun 2016, RAB tidak diperinci pada RAB di LPK dan LPJ ${ }^{8}$ yang menyebabkan beberapa temuan pada biaya operasional. Dengan banyaknya temuan tersebut, pada tahun 2017 RAB pada KAK disusun lebih rinci, sehingga lebih efektif dalam mengenali item-item mana yang bisa menunjukkan potensi fraud.

Mengetahui temuan-temuan tersebut, melalui Keputusan Rektor PTKIN X Nomor 396 Tahun 2015, SPI diminta lebih ketat dalam menjalankan peranan penting dalam ranah monitoring dan evaluasi. Keberadaan SPI juga 
diperkuat dengan Peraturan Menteri Agama Nomor 25 Tahun 2017 tentang Satuan Pengawas Intern di Lingkungan Kementerian Agama ${ }^{10}$. Dengan demikian, tim SPI PTKIN $X$ juga menjadi bagian dalam mewujudkan pengelolaan anggaran yang sehat di internal kampus. Pernyataan ini sejalan dengan apa yang dikatakan oleh kepala bagian keuangan, yaitu:

"Tujuan kita sama. Harapannya dengan adanya SPI, kita bisa memaksimalkan daya serap anggaran dan meminimalkan potensi temuan. Tim keuangan dan tim SPI harus sevisi dalam menjalankan fungsi masing-masing"

Pernyataan kabag keuangan tersebut menekankan bahwa tim keuangan fokus pada penyerapan anggaran dan SPI pada potensi temuan. Pada tahun 2016, tingkat serapan anggaran PTKIN X 93,17\%. Harapan pada tahun 2017 serapan anggaran meningkat dan minim, bahkan terbebas dari temuan. Jadi, bukan saja mengejar nominal tinggi pada serapan anggaran, tetapi banyak temuan.

PTKIN ini SPI menjadi gerbang pertama atau bamper dalam pemeriksaan oleh auditor eksternal. Pernyataan ini sesuai dengan hasil wawancara dengan dengan ketua SPI, yaitu:

"SPI ini akan menjadi garda terdepan jika ada irjen datang. Jika ada yang perlu dikonfirmasi, pengguna anggaran tiap fakultas, unit, lembaga, atau bagian rektorat tidak perlu lagi menemui irjen. Cukup SPI saja dengan catatan untuk dokumen-dokumen yang sudah di-audit oleh SPI."

Pernyataan ketua SPI tersebut menunjukkan komitmen dan kesungguhan menjalankan tugas sebagai pengawas internal kampus walaupun pengelolaan keuangan rentan adanya fraud. Komitmen SPI tersebut diperkuat dengan adanya pelimpahan tanggung jawab dari pengguna anggaran kepada SPI jika dokumen pengelolaan anggaran sudah diaudit dan disetujui oleh SPI. Artinya, ketika auditor eksternal datang, maka SPI-lah yang menemui dan menjawab segala pertanyaan auditor eksternal, bukan lagi dari pihak pengguna anggaran.

Dalam melakukan tugas dan fungsi sebagai auditor internal, SPI PTKIN X memutuskan untuk melakukan pre-audit pada proposal penggunaan anggaran. Di lingkungan PTKIN, proposal dinamakan Kerangka Acuan Kerja (KAK). Untuk mewujudkan pre-audit yang berkualitas, ada beberapa kegiatan yang dilakukan.

Pertama, melakukan reviu atas Rencana Kerja dan Anggaran Kementerian Negara/ Lembaga (RKAKL) atau Petunjuk Operasional Kegiatan (POK) pada setiap fakultas, unit, dan lembaga. Selama ini RKAKL dianggap sebagai "kitab suci" dan dijadikan acuan oleh staff penyusun SPJ dalam mengajukan permohonan pencairan dana. RKAKL bukan dokumen yang pasti (fix) atau tidak bisa berubah selama masa anggaran, melainkan bisa dirubah selama tiga kali dalam setahun. Revisi RKAKL dilakukan agar pedoman sesuai dengan penggunaan anggaran.

Sebelum ada SPI, RKAKL direvisi oleh masing-masing fakultas, unit, lembaga, dan bagian rektorat sesuai dengan kebutuhan. Untuk tahun ini, sebelum revisi, RKAKL direviu terlebih dahulu oleh tim SPI. Untuk batas akhir revisi bisa sesuai dengan arahan kepala sub 
AKRUAL: Jurnal Akuntansi, volume 9, nomor 1, Oktober 2017, (54-64)

bagian perencanaan. Setelah RKAKL disahkan, maka siap menjadi pedoman dalam penyusunan Kerangka Acuan Kerja (KAK) sebagai dokumen permohonan pencairan anggaran.

Kedua, melakukan ex ante audit pada dokumen KAK. KAK merupakan gambaran umum dan penjelasan mengenai kegiatan yang akan dilaksanakan sesuai dengan tugas dan fungsi Kementerian Negara/Lembaga. KAK berisi tentang penjelasan atau keterangan mengenai apa, mengapa, siapa, kapan, di mana, bagaimana, dan berapa perkiraan biayanya suatu kegiatan. Dengan kata lain, KAK berisi uraian tentang latar belakang, tujuan, ruang lingkup, masukan yang dibutuhkan, dan hasil yang diharapkan dari suatu kegiatan. KAK mempunyai nama lain, yaitu Term Of Reference
(TOR) atau proposal. Namun, dalam PTKIN X lebih sering menggunakan istilah KAK.

Pendampingan penyusunan KAK secara konsep dilakukan secara bersama-sama oleh tim SPI, sedangkan secara teknis dilakukan oleh masing-masing auditor. Tim SPI yang beranggotakan 9 orang, masing-masing diberi tanggung jawab untuk mendamping satu hingga dua fakultas, unit, lembaga, atau bagian rektorat. Penetapan Person in Charge (PIC) ini diharapkan mampu menganalisis gejala sosial yang berkaitan dengan pengelolaan anggaran, sehingga dapat mengantisipasi adanya fraud di tingkat bawah. Pendampingan tersebut dilakukan mulai dari penganggaran hingga pelaporan penggunaan anggaran. Adapun alur dari pengajuan anggaran adalah sebagai berikut.

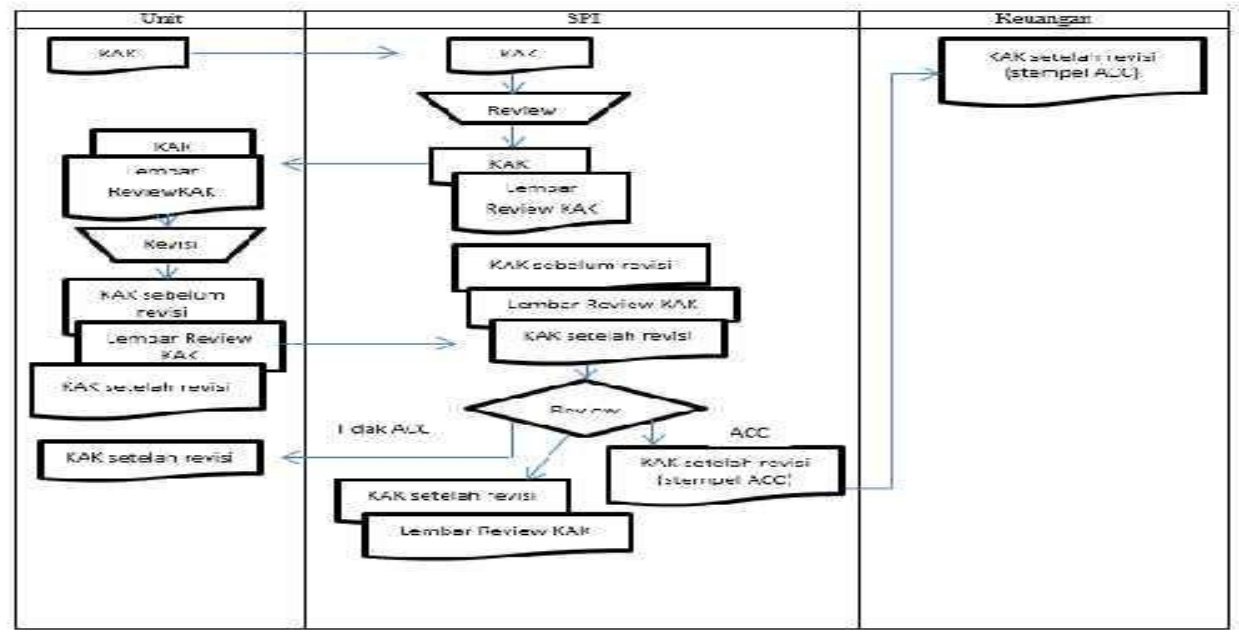

Sumber: Data primer yang diolah, 2017

Bagan alir tersebut menunjukkan bahwa KAK yang sudah disusun oleh fakultas, unit, lembaga, atau bagian rektorat harus diajukan dahulu ke SPI untuk dilakukan ex ante audit. Pada rangkaian ex ante audit ini, SPI mengeluarkan lembar hasil reviu, disetujui atau tidak disetujui. Jika tidak disetujui, maka KAK 60 dikembalikan ke penyusun KAK untuk direvisi sesuai rekomendasi auditor SPI. Setelah direvisi, kembali ke SPI untuk direviu hasil pengerjaan revisi tersebut. Setelah disetujui, auditor membubuhkan stempel pada cover KAK sebagai tanda bahwa KAK layak untuk masuk ke bagian keuangan.

Copyright $\odot 2017$ AKRUAL: Jurnal Akuntansi 
Pada PTKIN X ini, bagian keuangan baru akan memproses pencairan anggaran jika KAK sudah berstempel SPI. Kriteria kelayakan KAK yang ditandai oleh stempel SPI, dinilai dari format dan ketentuan KAK berdasarkan kelengkapan dokumen pendukung, relevansi antara anggaran dan jenis belanja, serta kewajaran harga.

Pemeriksaan kelengkapan dokumen pendukung dilakukan dengan menyesuaikan antara jenis kegiatan dan dokumen apa saja yang perlu dilampirkan pada KAK. Beda kegiatan, beda lampiran bukti pendukung. Adapun jenis kegiatan yang ada pada PTKIN $\mathrm{X}$ adalah pertemuan (rapat, seminar, pelatihan, workshop, sosialisasi, dll), penyaluran bantuan (rehabilitasi, operasional, insentif, beasiswa, dll), penyusunan dan tim Kerja (permenag, juklak, juknis, pendataan, penyusunan panduan/buku, dll), publikasi (penerbitan, konferensi pers, iklan, talkshow, dll), perjalanan (monitoring, pemetaan, dll), dan pelelangan (pengadaan, penggandaan, penunjukan, pemilihan, pemeliharaan, dll).

Adapun yang perlu dilampirkan pada KAK adalah dokumen yang mendukung dan mendeskripsikan kegiatan. Misalnya, lampiranlampiran yang minimal harus ada pada KAK jenis workshop: Jadwal atau rundown pelaksanaan; Profil narasumber dan moderator; Rencana anggaran belanja; Struktur kepanitiaan; Timeline pelaksanaan kegiatan. Selebihnya, lampiran bisa disesuaikan dengan jenis kegiatannya.
Dalam hal relevansi, auditor memeriksa kesesuaian antardokumen. Misalnya, jumlah jam narasumber harus sama dengan rentang waktu yang ada di rundown dan jumlah satuan harga pada rencana anggaran dan belanja. Kewajaran harga dilakukan dengan dengan cara mengoreksi apakah nominal rupiah yang tercantum dalam rencana anggaran dan belanja sudah sesuai dengan standar biaya masukan atau harga pasar. Standar biaya masukan merupakan batas maksimal anggaran merupakan rupiah maksimal yang boleh digunakan dalam pelaksanaan kegiatan. Batas maksimal ini disusun berdasarkan Peraturan Menteri Keuangan Nomor 33 Tahun 2016 Namun, tidak semua item tertuang dalam PMK tersebut, sehingga perlu adanya informasi tambahan yang berisi item barang yang sering dibeli di kegiatan, misalnya Alat Tulis Kantor (ATK). Dalam hal ini, SPI bekerja sama dengan rektorat bagian umum yang sering melakukan pengadaan ATK melakukan penyusunan standar biaya ATK sebagai dasar ex ante audit. Sebagian besar temuan pada item $\mathrm{RAB}$ tidak menunjukkan kondisi riil pada saat dilaksanakan. Misalnya, Alat Tulis Kantor tidak dirinci, sehingga menyulitkan auditor untuk mengecek kewajaran harga. Seharusnya, ATK dirinci hingga merk dan ukurannya.

Selain itu, juga dilakukan dengan melihat apakah volume pembelian sudah dalam batas kewajaran. Contoh potensi temuan ada pada pembelian kertas sejumlah sepuluh rim untuk kegiatan sosialisasi. Jumlah tersebut dinilai tidak wajar dan dipertanyakan penggunaannya. Relevansi jenis barang dengan 
AKRUAL: Jurnal Akuntansi, volume 9, nomor 1, Oktober 2017, (54-64)

kegiatan. Misalnya, seminar kit tidak sesuai dengan tema kegiatan.

\section{Temuan pada Ex Ante Audit}

Program baru tentunya membuat pengelola anggaran mengalami shock. Apalagi, dahulu (sebelum ada ex ante audit) tidak dipermasalahkan, sekarang (setelah ada ex ante audit) dipermasalahkan. Banyak complain, namun tetap harus sesuai dengan rekomendasi atas temuan pada dokumen perencanaan, KAK. Complain dilakukan karena pengelola anggaran merasa bertahun-tahun baik-baik saja, tiba-tiba disalahkan oleh auditor yang notabene baru beberapa tahun, bahkan dosen atau karyawan baru. Complain juga dilakukan karena adanya temuan SPI yang antarbulan berubah. Misalnya, dahulu RAB ditandatangai oleh pimpinan fakultas, unit, atau lembaga, trimester kedua ditandatangani oleh ketua pelaksana kegiatan. Perubahan ini dilakukan agar ketua pelaksana mengetahui dengan pasti jumlah anggaran yang akan digunakan. Pernyataan ini juga didukung oleh kabag keuangan yang menyatakan bahwa perubahan ini akan selalu ada mengingat antara pihak SPI dan keuangan selalu mengadakan evaluasi rutin tentang pelaksanaan ex ante audit.

Potensi fraud yang paling sering ditemukan pada KAK adalah: harga satuan melebihi standar biaya masukan ${ }^{19}$; item belanja tidak rinci; ketidaksesuaian anggaran dengan rundown acara; penggunaan satuan. Harga melebih satuan ditunjukan dengan adanya harga yang melebihi standar biaya pada masukan. Misalnya, makan seharusnya 30ribu, di RAB melebihi dari nominal tersebut.
Item belanja tidak dirinci ditunjukkan dengan tidak ditulisnya item-item pada sub tertentu. Misalnya, di RAB hanya tertulis ATK sejumlah sekian rupiah. Seharusnya, ATK apa saja yang akan dibeli harus rinci dari mulai jenis barang, merk, hingga volume. Rincian tersebut penting digunakan oleh auditor untuk kroscek kesesuaian dengan standar biaya yang ditetapkan bersama bagian pengadaan barang atau berdasarkan harga pasar.

Ketidaksesuaian anggaran dengan rundown acara ditunjukkan jumlah konsumsi yang dikeluarkan. Misalnya, acara hanya dua jam dan dilakukan pagi hari, maka seharusnya tidak ada makan siang. Selain berkaitan dengan konsumsi, ada juga tentang narasumber. Maksudnya, di RAB tercantum narasumber akan mengisi acara sebanyak 3 jam, tetapi di rundown menunjukkan kurang atau lebih dari 3 jam. Mengenai satuan, masih ada fakultas, unit, atau lembaga yang menggunakan satuan OJ pada moderator. Padahal, seharusnya OK. Kalau potensi temuan pada kesalahan satuan ini dibiarkan, maka anggaran akan lebih banyak.

Temuan ini disebabkan karena adanya human error sebagai dampak pergantian pengelola anggaran dan kurangnya sosialisasi tentang PMK. Selain itu, juga adanya ketidaktahuan bahwa apa yang dilakukannya merupakan potensi temuan. Apalagi, staff penyusun SPJ bukan lulusan akuntansi, sehingga tidak mengerti tentang kewajaran dan relevansi dalam penyusunan anggaran.

\section{Hambatan Pelaksanaan Ex Ante Audit}


Perubahan pasti mengundang dampak positif dan negatif. Dampak positif dari adanya ex ante audit adalah semakin efektivitas penggunaan anggaran, sedangkan dampak negatifnya akan menimbulkan konflik antara pelaku audit dan subjek penyusun objek yang diaudit. Di setiap pertemuan koordinasi yang diadakan oleh bagian keuangan pusat yang dihadiri oleh staff penyusun SPJ serta mengundang SPI, sering mengundang konflik di dalamnya. Ada staff unit yang mempertanyakan kinerja SPI yang sering merubah aturan tanpa pemberitahuan. Misalnya, sebelum tahun 2017 RAB ditandatangani oleh dekan, tahun 2017 ditandatangani oleh ketua panitia atau penanggungjawab kegiatan

Konflik yang terjadi pada masa transisi, sebelum dan sesudah dilakukannya ex ante audit, dikarenakan tidak siapnya menerima perubahan yang drastis pada aturan dalam penyusunan dokumen pengajuan hingga pencairan anggaran. Salah satu perubahan adalah dahulu KAK dari unit langsung disampaikan ke bagian keuangan untuk diproses, tahun ini perlu melewati SPI untuk dilakukan audit terlebih dahulu.

Ketidaksiapan perubahan juga dikarenakan oleh faktor sumber daya manusia, khususnya staff SPJ yang kebanyakan bukan dari lulusan akuntansi. Dengan demikian, ada ketidakpahaman tentang pelaksanaan ex ante audit dari mulai pentingnya dilakukan hingga dampaknya terhadap temuan pada PTKIN X.

\section{KESIMPULAN}

Penelitian ini memberikan gambaran bagaimana PTKIN melakukan upaya untuk mencegah fraud sekaligus untuk meminimalisasi temuan. Upaya yang dilakukan oleh PTKIN X mengacu pada teori ex ante audit yang mengacu pada penelitian Mark Schelker dan Reiner Eichenberger (2008). Pada prosesnya, ex ante audit disesuaikan dengan kegiatan perencanaan keuangan dalam rangkaian pencairan anggaran Kementerian Agama, khususnya PTKIN X.

Ex ante audit dilakukan dengan cara mengaudit proposal pencairan anggaran. Audit proposal atau Kerangka Acuan Kerja (KAK) bertujuan untuk mengetahui apa saja yang akan dibelanjakan. Proses audit mengacu pada kelengkapan dokumen, kewajaran harga, serta relevansi antara penggunaan dana dan jenis kegiatan.

Hasil penelitian ini diharapkan mampu dijadikan dasar audit di PTKIN yang lain dan evaluasi bagi PTKIN X. Berdasarkan kelemahan ex ante audit terkait dengan sumber daya manusia, yang ditunjuk sebagai penyusun SPJ sebaiknya karyawan yang mempunyai dasar kelimuan ekonomi, khususnya akuntansi. Kalaupun terpaksa tidak ada, pihak keuangan pusat mengalokasikan anggaran untuk rutin menyelenggarakan workshop tentang pengelolaan anggaran yang sesuai dengan aturan dan meminimalisasi potensi fraud.

Penelitian ini mempunyai keterbatasan, yaitu ex ante audit hanya pada audit dokumen kegiatan selain pengadaan barang dan jasa (akun 53). Untuk penelitian selanjutnya, bisa dilakukan penelitian pada audit kinerja dan barang milik negara. 
AKRUAL: Jurnal Akuntansi, volume 9, nomor 1, Oktober 2017, (54-64)

\section{DAFTAR PUSTAKA}

Albrecht, w. steve. dan conan c. Albrecht, chad o. Albrecht, Mark F.Zimbelman. (2009). Fraud Examination. Edisi 3.. Mason ohio: South-Western Cengage Learning

Bungin,Burhan. (2011). Metodologi Penelitian Kuantitatif. Jakarta : Kencana.

Creswell, J., W. (2012). Research design Pendekatan kualitatif, Kuantitatif dan Mixed; Cetakan ke-2, Yogyakarta: Pustaka Pelajar.

Johnson, E. N., Kuhn Jr, J. R., Apostolou, B. A., \& Hassell, J. M. (2012). Auditor perceptions of client narcissism as a fraud attitude risk factor. Auditing: $A$ Journal of Practice \& Theory, 32(1),203-219.doi.org/10.2308/ajpt50329

Krambia-Kapardis, M. and Zopiatis, A. (2010), "Investigating incidents of fraud in small economies: the case of Cyprus", Journal of Financial Crime, Vol. 17 No. 2, pp. 195209.doi.org/10.1108/135907910110338 $\underline{90}$

Maria Krambia Kapardis, Konstantinos Papastergiou. 2016. "Fraud victimization in Greece: room for improvement in prevention and detection", Journal of Financial Crime, Vol. 23 Issue: 2, pp.481500.doi.org/10.1108/jfc-02-2015-0010

Zarkasyi, M. W. (2008). Good Corporate Governance. Penerbit Alfabeta Bandung.

Asy'ari, M. A., \& Prasetyono, B. H. (2013). Peran Dan Fungsi Satuan Pengawasan Intern Dalam Pencegahan Fraud Pada Perguruan Tinggi $\mathrm{X}$.

Schelker, M., \& Eichenberger, R. (2008). Rethinking public auditing institutions: Empirical evidence from Swiss municipalities.https://doi.org/10.2139/s srn.1028927

Alim, M. N., \& Musyarofah, S. (2017). Memotret Pola Fraud Pada Rincian Objek Belanja Yang Menjadi Temuan Bpk. Journal of Auditing, Finance, And Forensic Accounting, 4(2), 101110.
Theodorus M. Tuanakotta. 2013. Audit Berbasis ISA. Jakarta : Penerbit Salemba Empat. 